\title{
Double-Stranded RNA-Degrading Enzymes Reduce the Efficiency of RNA Interference in Plutella xylostella
}

\author{
Jin-Zhi Chen ${ }^{1,2,3,4,5,+}$, Ying-Xia Jiang ${ }^{1,2,3,4,5,+}$, Miao-Wen Li ${ }^{1,2,3,4,5}$, Jian-Wen Li ${ }^{1,2,3,4,5}$, Ben-Hu Zha ${ }^{1,2,3,4,5}$ \\ and Guang Yang $1,2,3,4,5,6, *$
}

1 State Key Laboratory of Ecological Pest Control for Fujian and Taiwan Crops, Institute of Applied Ecology, Fujian Agriculture and Forestry University, Fuzhou 350002, China; chjinzhi@yeah.net (J.-Z.C.); jyx18270821925@163.com (Y.-X.J.); miaowenLee@163.com (M.-W.L.); li1928999798@163.com (J.-W.L.); benhu_zha@163.com (B.-H.Z.)

2 Joint International Research Laboratory of Ecological Pest Control, Ministry of Education, Fuzhou 350002, China

3 Key Laboratory of Integrated Pest Management for Fujian-Taiwan Crops, Ministry of Agriculture and Rural Affairs, Fuzhou 350002, China

4 Key Laboratory of Green Control of Insect Pests (Fujian Agriculture and Forestry University), Fujian Province University, Fuzhou 350002, China

5 Ministerial and Provincial Joint Innovation Centre for Safety Production of Cross-Strait Crops, Fujian Agriculture and Forestry University, Fuzhou 350002, China

6 College of Plant Protection, Fujian Agriculture and Forestry University, 15 Shangxiadian Road, Cangshan, Fuzhou 350002, China

* Correspondence: yxg@fafu.edu.cn; Tel.: +86-591-8379-7383

+ These authors contributed equally.

Citation: Chen, J.-Z.; Jiang, Y.-X.; Li, M.-W.; Li, J.-W.; Zha, B.-H.; Yang, G. Double-Stranded RNA-Degrading Enzymes Reduce the Efficiency of RNA Interference in Plutella xylostella. Insects 2021, 12, 712. https:// doi.org/10.3390/insects12080712

Academic Editor: Edward

B. Dubrovsky

Received: 11 July 2021

Accepted: 3 August 2021

Published: 9 August 2021

Publisher's Note: MDPI stays neutral with regard to jurisdictional claims in published maps and institutional affiliations.

Copyright: (c) 2021 by the authors. Licensee MDPI, Basel, Switzerland. This article is an open access article distributed under the terms and conditions of the Creative Commons Attribution (CC BY) license (https:/ / creativecommons.org/licenses/by/ $4.0 /)$.
Simple Summary: The efficiency of Lepidoptera RNA interference (RNAi) is highly varied among different species, different periods, and different genes. The stability of dsRNA is one of the important factors. DsRNA-degrading enzymes (dsRNases) are the key factors affecting the stability of dsRNA in insects. The efficiency of RNAi in diamondback moths was low and unstable. Furthermore, in vitro experiments, we found that dsRNA was completely degraded when incubated with the hemolymph or gut fluid of diamondback moths. Therefore, we hypothesized that the efficiency of RNAi in diamondback moths was decreased predominantly due to degradation of dsRNA by dsRNase. In this study, we identified four dsRNases in diamondback moths: PxdsRNase1 was mainly expressed in the hemolymph; and PxdsRNase2 and PxdsRNase3 were mainly expressed in the intestinal tract. PxdsRNase1, PxdsRNase2, and PxdsRNase3 were verified to be involved in the RNAi process in diamondback moths. In vitro, the recombinant protein of PxdsRNase1 degraded dsRNA completely and PxdsRNase 3 cleaved dsRNA without complete degradation. Overall, our findings provided a fundamental basis for understanding the mechanism of dsRNase involvement in the RNAi process and using RNAi to control diamondback moths in the future.

Abstract: DsRNA-degrading enzymes (dsRNases) have been recognized as important factors in reducing RNA interference (RNAi) efficiency in different insect species. However, dsRNases in Plutella xylostella are still unknown. We identified the full-length cDNAs of PxdsRNase1, PxdsRNase2, PxdsRNase3, and PxdsRNase4. Gene expression profile showed that PxdsRNase1 was mainly expressed in the hemolymph; and that PxdsRNase 2 and PxdsRNase3 were mainly expressed in the intestinal tract. The expression of PxCht (Chitinase of P. xylostella) in P. xylostella larvae injected with the mixture of dsPxCht (dsRNA of PxCht) and dsPxdsRNase1 (dsRNA of PxdsRNase1), dsPxdsRNase2 (dsRNA of PxdsRNase2), or dsPxdsRNase3 (dsRNA of PxdsRNase3) was significantly higher than that in the larvae injected with the mixture of dsGFP (dsRNA of green fluorescent protein gene, GFP) and dsPxCht; the transcription level of PxCht in the larvae feeding on the mixture of dsPxCht and dsPxdsRNase1, dsPxdsRNase2, or dsPxdsRNase3 was significantly higher than that in the larvae feeding on the mixture of dsPxCht and dsGFP. The recombinant protein of PxdsRNase1 degraded dsRNA rapidly, PxdsRNase3 cleaved dsRNA without complete degradation, and PxdsRNase2 could not degrade dsRNA in vitro. These results suggested that PxdsRNases1, PxdsRNases2, and 
PxdsRNases3 were involved in the dsRNA degradation to reduce RNAi efficiency with different mechanisms.

Keywords: dsRNase; RNA interference; diamondback moth; RNA degradation

\section{Introduction}

The efficiency of Lepidoptera RNAi is highly varied among different species, different periods, and different genes [1]. The dsRNA degradation [2-4] or the inability of dsRNA to enter the cytoplasm $[3,5,6]$ are the main factors affecting RNAi efficiency. Studies have also shown that dsRNA needs to last long enough in the midgut or hemolymph to be absorbed into cells to produce an effective RNAi response [7]. DsRNases are the key factors affecting the stability of dsRNA in insects. The activity of dsRNase has been observed in several insects. In Bombyx mori, dsRNase is expressed in the digestive juice and midgut, then secreted into the intestinal cavity for nucleic acid digestion [8,9]. Subsequently, dsRNases are found in more and more insects, such as Lygus lineolaris [10], Manduca sexta [11], Acyrthosiphon pisum [12], Schistocerca gregaria [13], and Spodoptera frugiperda [14].

In the hemolymph of $M$. sexta, dsRNA is degraded within $1 \mathrm{~h}$, which proves the presence of dsRNase [11]. The RNAi efficiency is increased after the expression of dsRNase in Locust migratoria and S. gregaria is suppressed [15], verifying that the RNAi efficiency could be affected by dsRNase in insects. Furthermore, in Anthonomus grandis, the RNAi sensitivity is increased after dsRNA of nuclease is ingested to suppress the nuclease activity [16]. Interestingly, multiple dsRNases working together could enhance their effect on RNAi efficiency in Spodoptera litura $[17,18]$. The RNAi efficiency is increased after knockdown of RNAi efficiency-related nucleases (REases) in Ostrinia furnacalis, and suppressed after up-regulation of REase in Drosophila melanogaster [19].

With in vitro experiments, we found that dsRNA was completely degraded when incubated with the hemolymph or gut fluid of $P$. xylostella. Therefore, we hypothesized that the efficiency of RNAi in P. xylostella was decreased predominantly due to degradation of dsRNA by dsRNase. To verify this hypothesis, we performed a genome-wide search to identify genes encoding dsRNases in the P. xylostella and conducted function analysis of these dsRNases to understand the role of dsRNases in the RNAi process in P. xylostella.

\section{Materials and Methods}

\subsection{Insect Rearing}

The P. xylostella Fuzhou-sensitive strain (FZss) used in the experiment was maintained at the Institute of Applied Ecology, Fujian Agriculture and Forestry University, Fuzhou, China. The colony was maintained on radish (Raphanus sativus) seedlings without exposure to any chemical insecticide at $25^{\circ} \mathrm{C}$ with the photoperiod of $16 \mathrm{~L}$ : $8 \mathrm{D}$ and $60-70 \%$ relative humidity $(\mathrm{RH})$ in the growth chamber.

The P. xylostella sensitive strain (SLss) was reared by the artificial diet [20]. Pupae were collected in a paper cup with a cotton wool containing $10 \%$ honey as extra nutrition for adults, and eggs were collected by a parafilm card stained with vegetable powder hung in the cup. The insect was reared at $26 \pm 1{ }^{\circ} \mathrm{C}, 60-80 \% \mathrm{RH}$, and the photoperiod of 16L: 8D.

\subsection{Isolation and Sequencing of PxdsRNase cDNAs}

The BmdsRNase (dsRNase of B. mori, GenBank ID: NP_001091744.1) was used as a query in tBLASTn to search the genomic database of P. xylostella (http://59.79.254. 1/DBM/blast.php (accessed on 24 October 2017)) for obtaining the cDNA sequence of PxdsRNase. Total RNA was extracted from the 4th-instar larvae using the RNA extraction kit (Promega, Madison, WI, USA), according to the manufacturer's instructions. Firststrand complementary DNA (cDNA) synthesis was performed from $1 \mu \mathrm{g}$ of total RNA using the reverse transcription kit (Promega, Madison, WI, USA). PCR was performed with 
the cDNA template and gene-specific primers (Table 1) to amplify the full-length cDNA sequence of PxdsRNase in the following conditions: $95^{\circ} \mathrm{C}$ for $5 \mathrm{~min} ; 35$ cycles of $95{ }^{\circ} \mathrm{C}$ for $30 \mathrm{~s}, 55^{\circ} \mathrm{C}$ for $15 \mathrm{~s}$, and $72{ }^{\circ} \mathrm{C}$ for $2 \mathrm{~min}$; and $72{ }^{\circ} \mathrm{C}$ for $10 \mathrm{~min}$. The PCR product was purified using the E.Z.N.A ${ }^{\mathrm{TM}}$ Gel Extraction kit (Omega, Doraville, GA, USA), inserted into the pESI-Blunt Zero plasmid (Yeasen, Shanghai, China), and then sequenced in two directions by Shangya Biological Company (Fuzhou, China).

Table 1. Primers used in the experiment.

\begin{tabular}{|c|c|c|}
\hline Use of Primers & Gene & Primer Sequence $\left(5^{\prime}-3^{\prime}\right)$ \\
\hline \multirow{4}{*}{ cDNA cloning } & PxdsRNase1 & $\begin{array}{l}\text { F: ATGCTTCACAAATGGGTTCTAATG } \\
\text { R: TCACAGTAGTAATCCAGTGACTTTG }\end{array}$ \\
\hline & PxdsRNase2 & $\begin{array}{c}\text { F: ATGATGTTGCGTGGTTGTGTGC } \\
\text { R: TTAAACTAAAAGCCCATTCACGGTAAAAG }\end{array}$ \\
\hline & PxdsRNase3 & $\begin{array}{c}\text { F: ATGCTGCGTCCTTGTCTGC } \\
\text { R: TTAAGCCAACAGCCCATTAACTTTG }\end{array}$ \\
\hline & PxdsRNase4 & $\begin{array}{l}\text { F: ATGATTCACAAAAAACTTTTACAAG } \\
\text { R: TTACACTTTCTTTCCGTTGATGCTAG }\end{array}$ \\
\hline \multirow{6}{*}{ qPCR primer } & PxdsRNase1 & $\begin{array}{l}\text { F: GCGCGAATTGTACCCTCTGT } \\
\text { R: GGACTCAGCAGCCAATCAAC }\end{array}$ \\
\hline & PxdsRNase2 & $\begin{array}{l}\text { F: GGGCGTATGGAGTCTTCCTG } \\
\text { R: CGAACTCCTCTTCTCCCAGC }\end{array}$ \\
\hline & PxdsRNase3 & $\begin{array}{l}\text { F: CGGACACTCCTTCCACGAC } \\
\text { R: TGTAGCCGACCCTGATGACC }\end{array}$ \\
\hline & PxdsRNase4 & $\begin{array}{l}\text { F: AAGTAGCCCAACTCAGTGCC } \\
\text { R: AGCAGACACGGTCCCGAATA }\end{array}$ \\
\hline & $E F 1$ & $\begin{array}{l}\text { F: GCCTCCCTACAGCGAATC } \\
\text { R: CCTTGAACCAGGGCATCT }\end{array}$ \\
\hline & PxCht & $\begin{array}{l}\text { F: AGACTTGATGGTGTTCGCGT } \\
\text { R: GTCCACCTTCTGCCCTATCG }\end{array}$ \\
\hline \multirow{6}{*}{ dsRNA primer } & dsPxdsRNase1 & $\begin{array}{l}\text { F: TAATACGACTCACTATAGGGTAGATGCTCCTCACCTCCA } \\
\text { R: TAATACGACTCACTATAGGGTCTCTCCGAACGCAAACAC }\end{array}$ \\
\hline & dsPxdsRNase2 & $\begin{array}{l}\text { F: TAATACGACTCACTATAGGGGTGGAGGATGGTAAAGCGAC } \\
\text { R: TAATACGACTCACTATAGGGGTGGCGAACACAAAGTCCGT }\end{array}$ \\
\hline & dsPxdsRNase3 & $\begin{array}{l}\text { F: TAATACGACTCACTATAGGGTCCAAGACTGTGGCTACTGC } \\
\text { R: TAATACGACTCACTATAGGGGTCAGATGCCCTCGGTTCAA }\end{array}$ \\
\hline & dsPxdsRNase4 & $\begin{array}{l}\text { F: TAATACGACTCACTATAGGGCGGGTTCCTAACTGGGTGTT } \\
\text { R: TAATACGACTCACTATAGGGCCACCGAGTTGCCTCCTATC }\end{array}$ \\
\hline & dsPxCht & $\begin{array}{l}\text { F: TAATACGACTCACTATAGGGAACGAAAAGGTCTGGATCTG } \\
\text { R: TAATACGACTCACTATAGGGGGGTGGTCTCAGCCTAACAT }\end{array}$ \\
\hline & dsGFP & $\begin{array}{l}\text { F: TAATACGACTCACTATAGGGGCTTCTCGTTGGGGTCTTTG } \\
\text { R: TAATACGACTCACTATAGGGACCACATGAAGCAGCACGAC }\end{array}$ \\
\hline
\end{tabular}

Note: The underline sequence represents the sequence of $\mathrm{T} 7$ promoter.

\subsection{Amino Acid Sequence Analysis of PxdsRNases}

The cDNA sequences of $P x d s R N a s e s$ were translated into the amino acid sequence by the online tools available from the ExPASy website (https: / /web.expasy.org/translate/ (accessed on 16 November 2017)). Domain architecture and signal peptides were predicted by the SMART domain analysis (http:/ / smart.embl-heidelberg.de / (accessed on 16 November 2017)) and the SignalP 4.1 Server (http:/ / www.cbs.dtu.dk/services/Sig-nalP / (accessed on 16 November 2017)), respectively. Web BLAST tools (https:/ /blast.ncbi.nlm.nih.gov/ 
(accessed on 16 November 2017)) were used to analyze the conserved regions, including the endonuclease NS domain, active site, $\mathrm{Mg}^{2+}$ binding site, and substrate binding site.

\subsection{Determination of Gene Expression of PxdsRNase Genes in Different Tissues and Developmental Stages}

For tissue-specific expression of PxdsRNase genes, the total RNA was extracted from the integument, fat body, gut, malpighian tubule, hemolymph, silk and head of 20 4thinstar larvae. For determining the gene expression in different developmental stages, the total RNA was extracted from eggs, 1st, 2nd, 3rd, 4th larvae, pupae and adults. The first-strand cDNA was synthesized from $1 \mu \mathrm{g}$ of total RNA using the reverse transcription kit (Promega, Madison, WI, USA). PxdsRNase-, PxCht-, EF1-specific primers used for the quantitative PCR (qPCR) are shown in Table 1. Each $20 \mu \mathrm{L}$ of qPCR mixture consisted of $10 \mu \mathrm{L}$ SYBR ${ }^{\mathrm{TM}}$ Green Real-time PCR Master Mix (Progema, Madison, WI, USA), $2 \mu \mathrm{L}$ of 10 -fold diluted template cDNA, $0.4 \mu \mathrm{L}$ of $10 \mu \mathrm{M}$ of each primer, $0.15 \mu \mathrm{L}$ of ROX and $7.05 \mu \mathrm{L}$ of deionized water. The PCR reaction conditions were $95^{\circ} \mathrm{C}$ for $10 \mathrm{~min}, 40$ cycles of $95^{\circ} \mathrm{C}$ for $15 \mathrm{~s}$, and $60^{\circ} \mathrm{C}$ for $30 \mathrm{~s}$. A melt curve was developed to confirm the amplification specificity for each qPCR. Three technical replicates of each qPCR and three biological replicates of each treatment were conducted. Gene expression level was analyzed using the $2^{-\triangle \mathrm{CT}}$ method, and statistical analyses were performed using one-way ANOVA (analysis of variance) followed by the Turkey test ( $p<0.05$, SPSS software, SPSS Inc. Chicago, IL, USA).

\subsection{In Vitro Incubation of dsRNA with Hemolymph/Gut Fluid}

Hemolymph was collected with a capillary glass tube from the amputated legs of 30 4th-instar larvae, diluted with $50 \mu \mathrm{L}$ of PBS, and then centrifuged at $16,000 \times g$ for $10 \mathrm{~min}$ to remove hemocytes. The supernatant was collected and stored at $-20^{\circ} \mathrm{C}$. Meanwhile, guts from 30 larvae of P. xylostella were dissected and collected in cold $1.5 \mathrm{~mL}$ tubes with $50 \mu \mathrm{L}$ of $1 \times$ PBS buffer, and centrifuged at $16,000 \times g$ for $10 \mathrm{~min}$. The supernatant was collected and stored at $-20^{\circ} \mathrm{C}$.

The total protein concentration of the hemolymph or gut fluid was examined using the BCA Protein Quantification kit (Yesea, Shanghai, China), according to the manufacturer's instruction. Measurements were performed in the Synergy Mx microplate reader (BioTek, Doraville, GA, USA).

For an in vitro incubation assay, $1 \mu \mathrm{L}$ of dsPxCht solution (containing $120 \mathrm{ng}$ of dsRNA, $564 \mathrm{bp}$ ) was mixed with $10 \mu \mathrm{g}$ of total protein of hemolymph or gut fluid in $1.5 \mathrm{~mL}$ microcentrifuge tube and incubated at $28^{\circ} \mathrm{C}$ for $0 \mathrm{~min}, 5 \mathrm{~min}, 30 \mathrm{~min}, 60 \mathrm{~min}$, $360 \mathrm{~min}$, and $600 \mathrm{~min}$, separately. Next, $120 \mathrm{ng}$ of dsCht was mixed with $1 \mu \mathrm{g}, 5 \mu \mathrm{g}, 10 \mu \mathrm{g}$, $20 \mu \mathrm{g}$, and $30 \mu \mathrm{g}$ of total protein of hemolymph or gut fluid in 1.5-mL microcentrifuge tube and incubated at $28^{\circ} \mathrm{C}$ for $5 \mathrm{~min}$. After incubation, these samples were mixed with $1 \mu \mathrm{L}$ of loading buffer and checked in $1 \%$ agarose gel. The gel was visualized using a UV transilluminator (Vilber, Pairs, France) to analyze the integrity of dsRNA.

\subsection{RNAi Response after dsRNA Injection or Oral Delivery}

DsRNAs were prepared in vitro by the T7 RiboMAX Express RNAi System (Promega, USA). Primers (Table 1) for dsRNA synthesis of PxCht (564 bp), GFP (417 bp) and PxdsRNases (407 bp of PxdsRNases1, 476 bp of PxdsRNases2, 458 bp of PxdsRNases3, and 412 bp of PxdsRNases4) were designed using the NCBI web service (https:/ / www.ncbi.nlm.nih.gov/ tools/primer-blast/ (accessed on 8 May 2018)). The templates containing the T7 promoter sequence at both ends were synthesized through PCR by $2 \times$ Taq Master Mix (Vazyme, Nanjing, China). The PCR was performed at the condition: $94{ }^{\circ} \mathrm{C}$ for $5 \mathrm{~min} ; 35$ cycles of $95^{\circ} \mathrm{C}$ for $30 \mathrm{~s}, 55^{\circ} \mathrm{C}$ for $30 \mathrm{~s}$, and $72{ }^{\circ} \mathrm{C}$ for $40 \mathrm{~s}$; and $72{ }^{\circ} \mathrm{C}$ for $10 \mathrm{~min}$. The PCR products were purified using the E.Z.N.A ${ }^{\mathrm{TM}}$ Gel Extraction Kit (Omega, Doraville, GA, USA). About $2 \mu \mathrm{g}$ of each purified PCR product was used to synthesize dsRNA, dsRNA was dissolved with $20 \mu \mathrm{L}$ of nuclease-free water, and the final concentration of dsRNA was adjusted to $4.0 \mu \mathrm{g} / \mu \mathrm{L}$. 
To compare the RNAi responses induced by dsRNA between injection and oral delivery, PxCht involved in the molting process was selected as the RNAi target gene. DsGFP, dsPxdsRNase, the mixture of dsGFP and dsPxCht, and the mixture of dsPxCht and dsPxdsRNase were separately injected into the internode of abdomen of one 4th-instar larva of FZss at the amount of $600 \mathrm{ng}$ by a microsyringe and separately fed to the 100 larvae at the amount of $3 \mu \mathrm{g}$. All the treated larvae were reared in the same condition, as previously described. The total RNA of 5 larvae were extracted for each treatment, and RT-qPCR was performed with the primers listed in Table 1 to determine the expression of PxCht and PxdsRNase using EF1 as the reference gene. Three replications were performed for each treatment. The Turkey test after one-way ANOVA was used for determining differences in RNAi efficiency among different treatments.

\subsection{Heterologous Expression of PxdsRNases}

The codon-optimized cDNA sequences of PxdsRNase1, PxdsRNase2, and PxdsRNase3 without the signal peptide and with $6 \times$ His tags attached at its $3^{\prime}$ end, were individually inserted at NdelI/HindIII in PET-30a(+) vector by the Genscript Biotech Corporation (Nanjing, China). The constructed plasmids were individually transformed into E. coli DH5 $\alpha$ competent cells, and the subsequent cells were cultured at $37^{\circ} \mathrm{C}$ for $14 \mathrm{~h}$. Positive clones were picked and verified by PCR and sequencing.

The recombinant plasmid extracted from the transformed E. coli DH5 $\alpha$ was transformed into E. coli BL21 (DE3). Then, the dsRNases were expressed by the method of He et al. [21], and extracted by the ultrasonically crushing method [22]. The extracted proteins were identified by SDS-PAGE and Western blot.

\subsection{Determination of PxdsRNase Activity}

The protein concentration was determined as the method described in 2.5. To test the dsRNA-degrading activity of PxdsRNase, $1 \mu \mathrm{g}$ dsRNA dissolved in $5 \mu \mathrm{L}$ of nuclease-free water was added to $20 \mu \mathrm{L}$ of recombinant enzyme solution of PxdsRNase1 (1 $\mu$ g, $2 \mu \mathrm{g}$, $3 \mu \mathrm{g}, 4 \mu \mathrm{g}$, and $5 \mu \mathrm{g})$, PxdsRNase $2(5 \mu \mathrm{g}, 10 \mu \mathrm{g}, 15 \mu \mathrm{g}, 20 \mu \mathrm{g}$, and $30 \mu \mathrm{g})$, or PxdsRNase 3 $(1 \mu \mathrm{g}, 2 \mu \mathrm{g}, 3 \mu \mathrm{g}, 4 \mu \mathrm{g}$, and $5 \mu \mathrm{g})$, and then incubated at $28^{\circ} \mathrm{C}$ for $15 \mathrm{~min}$. After incubation, the samples were examined as the method described in Section 2.5.

\section{Results}

\subsection{Identification of DsRNases in P. xylostella}

Four cDNA sequences putatively encoding PxdsRNase1 (GenBank: MZ517187), PxdsRNase2 (GenBank: MZ517188), PxdsRNase3 (GenBank: MZ517189), and PxdsRNase4 (GenBank: MZ517190) were identified from P. xylostella genome. The cDNA sequences were cloned by RT-PCR and sequenced. The ORFs of these four genes were of $1212 \mathrm{bp}, 1359 \mathrm{bp}$, $1350 \mathrm{bp}$ and $939 \mathrm{bp}$, encoding 403, 451, 449 and 312 amino acids, respectively. The domain analyses showed that all enzymes contained an endonuclease NS domain and a signal peptide, except PxdsRNase4 which did not have a signal peptide (Figure 1A). Alignment of the endonuclease domains of PxdsRNases indicated that their amino acid sequences were of high identity, with six active sites, three substrate binding sites, and an $\mathrm{Mg}^{2+}$ binding site (Figure 1B). 
A

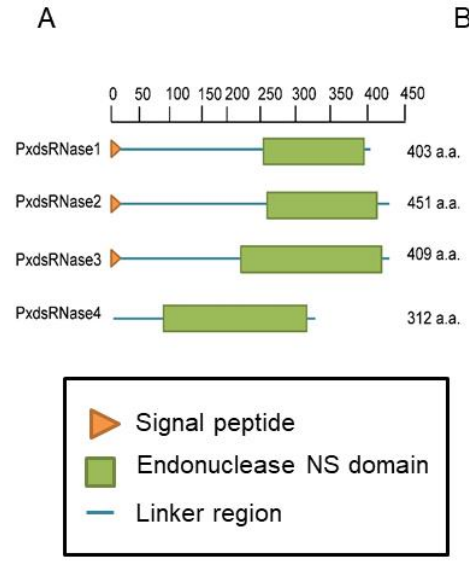

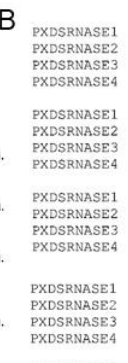

PXDSRNASE1
PXDSRNASE2
PXDSRNASE3
PXDSRNASE4
PXDSRNASE1
PXDSRNASE2
PXDSRNASE3
PXDSRNASE4

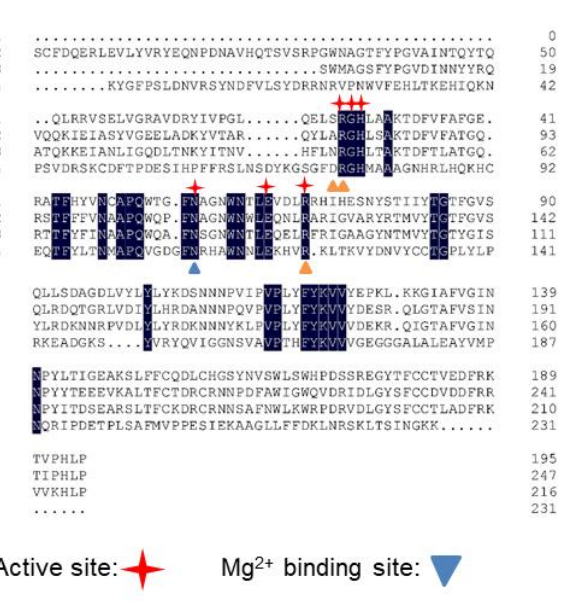

Substrate binding site:

Figure 1. Analysis of deduced amino acid sequences of PxdsRNase genes. (A) Schematic diagram of deduced amino acid domains of PxdsRNase1, PxdsRNase2, PxdsRNase3 and PxdsRNase4. An orange triangle stands for the location of signal peptide, green boxes endonuclease NS domains, and blue lines linker regions. (B) Multiple sequence alignments of endonuclease NS domain of deduced dsRNase amino acid sequences in P. xylostella.

\subsection{Stage-Specific and Tissue-Specific Expression of PxdsRNase Genes}

In general, $P x d s R N a s e$ genes had the highest expression levels of mRNA in the fourth instar larvae; $P x d s R N a s e 1$ had a lower expression level compared with other three $P x d$ sRNase genes in P. xylostella (Figure 2A). In different stages, PxdsRNase2 and PxdsRNase3 exhibited high expression in the second-fourth instar larvae; and PxdsRNase4 had high expression from the second instar larva to adult (Figure 2A). In different tissues, PxdsRNase1 had the highest expression level in the hemolymph; PxdsRNase2 and PxdsRNase 3 were almost exclusively expressed in the gut with a higher level of PxdsRNase2 than PxdsRNase3; and PxdsRNase4 had high expression level in the head, integument, and gut (Figure 2B).

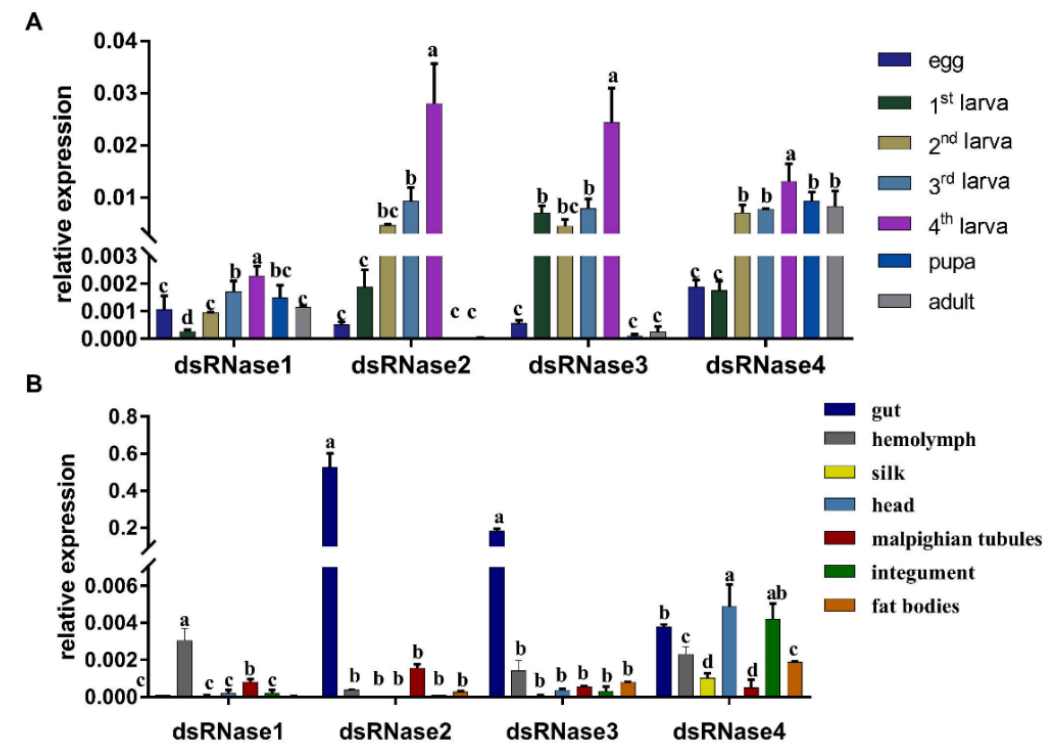

Figure 2. Relative expression levels of PxdsRNase genes. (A) Relative expression levels of PxdsRNase genes in different stages; (B) Relative expression levels of PxdsRNase genes in different tissues of the fourth instar larvae. EF1 was used as the reference gene. One-way ANOVA was conducted to calculate the statistical significance, followed by the Turkey test. Different letters on the bars represent significant differences $(p<0.05)$ among different samples. 


\subsection{DsRNA Degradation by the Proteins Extracted from the Gut and Hemolymph of Larvae}

DsRNA of $120 \mathrm{ng}$ was totally degraded by $10 \mu \mathrm{g}$ of total proteins extracted from the gut or hemolymph in $6 \mathrm{~h}$ at $28^{\circ} \mathrm{C}$ (Figure $3 \mathrm{~A}, \mathrm{~B}$ ), indicating that the enzymes in the gut or hemolymph could degrade the dsRNA. The total proteins of $30 \mu \mathrm{g}$ extracted from the gut and $20 \mu \mathrm{g}$ of total proteins extracted from the hemolymph degraded $120 \mathrm{ng}$ of dsRNA in $15 \mathrm{~min}$ at $28^{\circ} \mathrm{C}$, individually, which indicated that the hemolymph proteins might have a higher ability to degrade dsRNA than the gut proteins (Figure 3C,D).

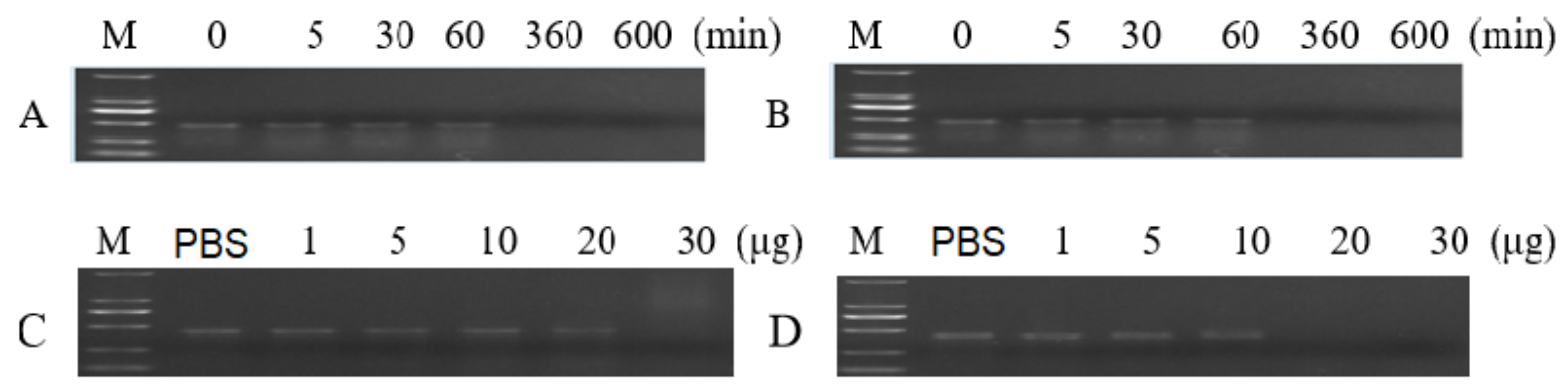

Figure 3. Degradation of dsRNA by the total proteins extracted from the gut or hemolymph at $28^{\circ} \mathrm{C}$. (A) Incubation of $120 \mathrm{ng}$ dsRNA with $10 \mu \mathrm{g}$ of total gut proteins for different times. (B) Incubation of $120 \mathrm{ng}$ dsRNA with $10 \mu \mathrm{g}$ of total hemolymph proteins for different times. (C) Incubation of $120 \mathrm{ng}$ dsRNA with 1-30 $\mu \mathrm{g}$ of total gut proteins for $5 \mathrm{~min}$. (D) Incubation of $120 \mathrm{ng}$ dsRNA with 1-30 $\mu \mathrm{g}$ of total hemolymph proteins for $5 \mathrm{~min}$.

\subsection{Effects of PxdsRNase Suppression on RNAi Efficiency}

In the injection experiment, the expression levels of $P x d s R N a s e 1$ were significantly suppressed by dsRNA at $36 \mathrm{~h}$ and $48 \mathrm{~h}$, PxdsRNase 2 at $24 \mathrm{~h}$ and $36 \mathrm{~h}, P x d s R N a s e 3$ at $24 \mathrm{~h}$, and PxdsRNase4 at $48 \mathrm{~h}$ (Figure 4). Co-injection of dsPxdsRNase1/dsPxdsRNase2/dsPxdsRNase3 + dsPxCht $(1 / 2 / 3+\mathrm{C})$ caused significant reduction in the transcript levels of PxCht compared with dsGFP +dsPxCht $(G+C)$ (Figure $5 A-C)$, but not with dsPxdsRNase4 + dsPxCht $(4+C)$ (Figure 5D). Therefore, RNAi efficiency in P. xylostella was improved after suppression of PxdsRNas1, PxdsRNas2, or PxdsRNas3 by dsRNA injection.

In the feeding experiment, the expression level of PxdsRNas1 in the larvae showed a significant reduction at $60 \mathrm{~h}$ post-feeding on dsPxdsRNase1 (Figure 6A), as well as PxdsRNase2 (Figure 6B). Interestingly, there was no suppression observed by dsPxdsRNase3 (Figure 6C) and dsPxdsRNase4 (Figure 6D). The expression level of PxCht in the larvae feeding on dsPxdsRNase $1+\mathrm{dsPxCht}(1+\mathrm{C})$ was significantly lower than that in the larvae feeding on dsGFP + dsPxCht $(G+C)$, and the same case for dsPxdsRNase $2+$ dsPxCht $(2+\mathrm{C})$ and dsPxdsRNase $4+\mathrm{dsPxCht}(4+\mathrm{C})$ (Figure 7A). The expression level of PxCht in the larvae feeding on dsPxdsRNase $3+$ dsPxCht $(3+\mathrm{C})$ was not changed compared with that in the larvae feeding on dsGFP+ dsPxCht $(G+C)$ (Figure 7A). The expression of PxdsRNase1 was observed to be significantly suppressed by dsPxdsRNase4 (Figure 7B). Therefore, oral administration of dsPxdsRNase4 might increase the RNAi efficiency by suppressing PxdsRNase1. The above results indicated that the RNAi efficiency in P. xylostella was enhanced after suppression of PxdsRNase1 and PxdsRNase2. 
A

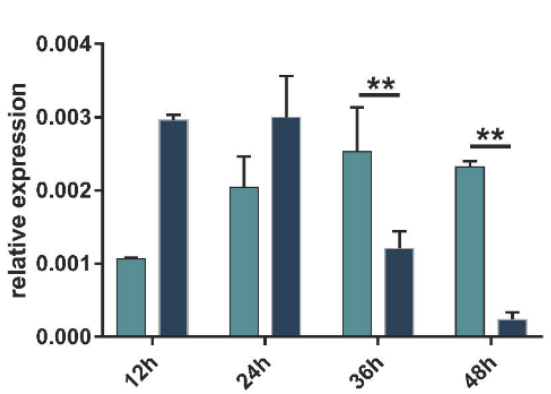

B

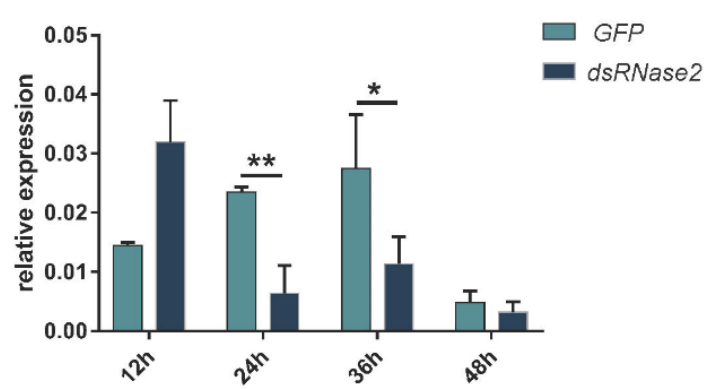

C
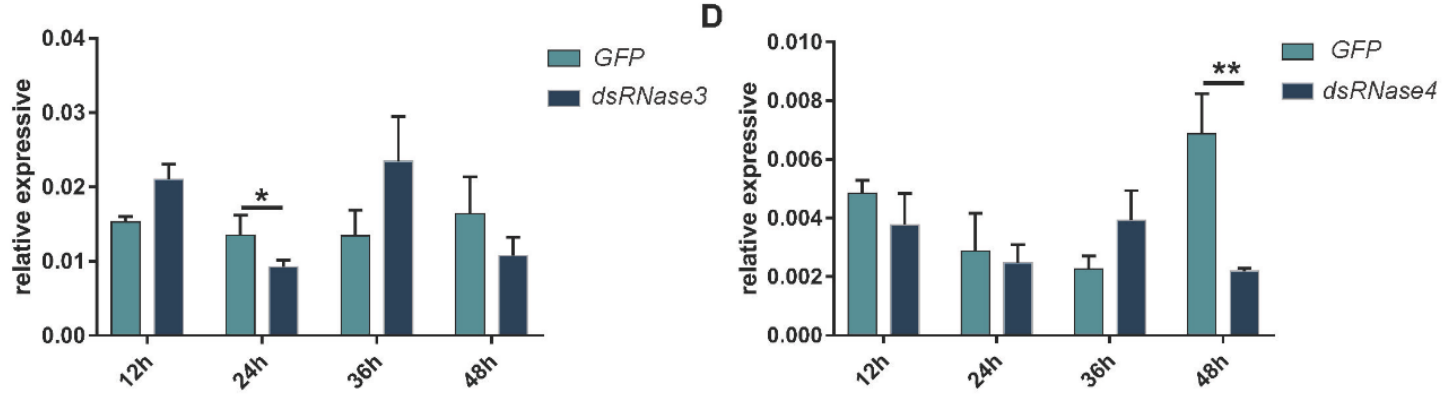

Figure 4. Effects of dsRNA injection on the expression levels of PxdsRNases. The fourth instar larvae were injected with $600 \mathrm{ng}$ of different dsPxdsRNases or dsGFP, and the transcription levels of PxdsRNase genes were detected by RT-qPCR at different times. EF1 was used as the reference gene for normalization. Statistical analyses were performed using one-way ANOVA followed by the Turkey test. (A) PxdsRNase1; (B) PxdsRNase2; (C) PxdsRNase3; (D) PxdsRNase4. $\quad{ }^{*}, p<0.05$; $* *, p<0.01)$.

A

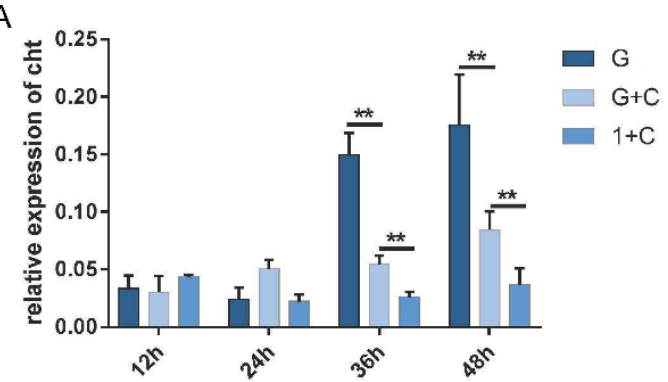

C

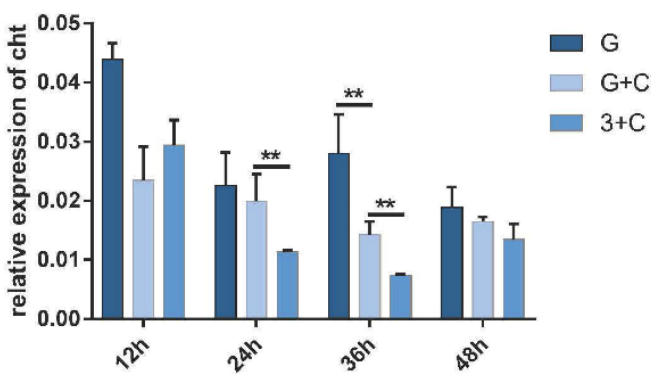

B

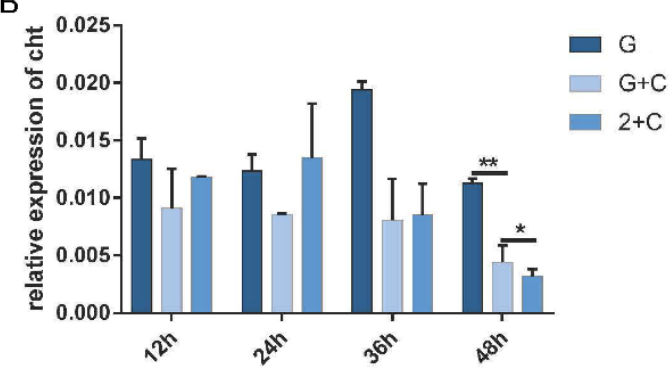

D

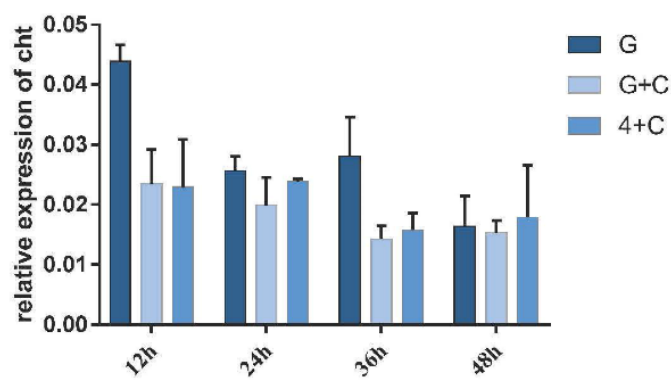

Figure 5. RNAi efficiency of $P x C h t$ after RNAi of $P x d s R N a s e$ by dsRNA injection. RNAi efficiency of $P x C h t$ in the $\mathrm{f}$ instar larvae after injection with $1200 \mathrm{ng}$ of dsGFP, a mixture of ds PxCht and dsGFP, or a mixture of dsPxdsRNase and dsPxcht, was evaluated by RT-qPCR, and EF1 was used as the reference gene for normalization. Statistical analyses were performed using one-way ANOVA followed by the Turkey test. G, dsGFP; C, dsPxCht; 1, dsPxdsRNase1; 2, dsPxdsRNase2; 3, dsPxdsRNase3; and 4, dsPxdsRNase4. (A) PxdsRNase1; (B) PxdsRNase2; (C) PxdsRNase3; (D) PxdsRNase4. $\left({ }^{*}, p<0.05\right.$; $* *, p<0.01)$. 
A

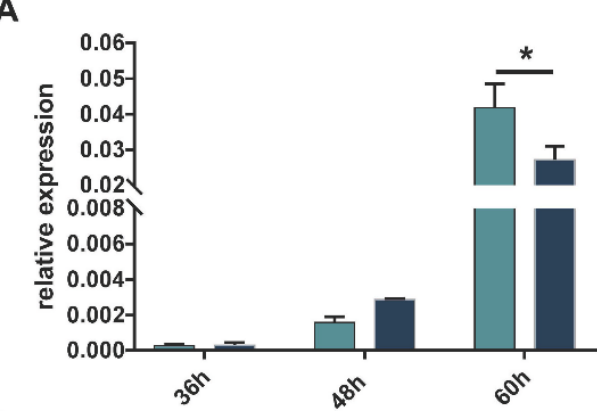

C

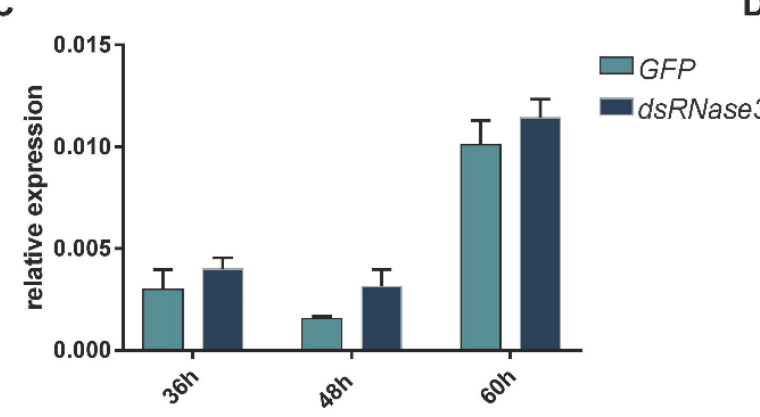

B

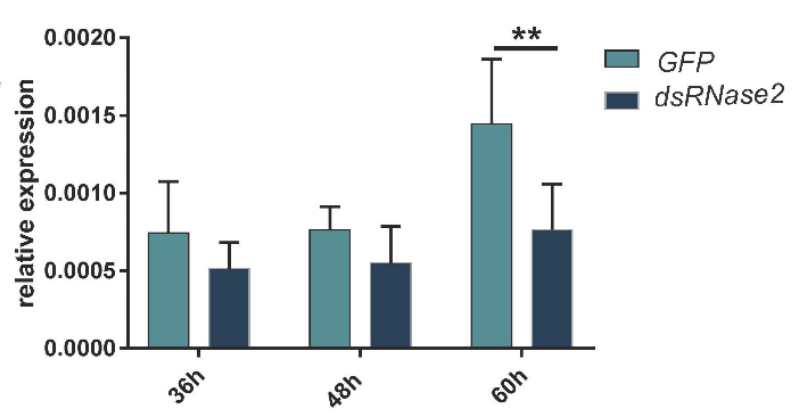

D

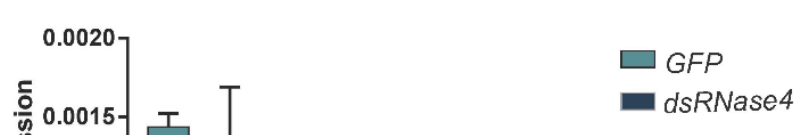

Figure 6. Effects of uptake dsRNA on relative expression levels of $P x d s R N a s e$ genes in the larvae. Three $\mu \mathrm{g}$ of dsPxdsRNase (dsPxdsRNase1, dsPxdsRNase2, dsPxdsRNase3 or dsPxdsRNase4) or dsGFP were fed to the fourth instar larvae, and the transcription levels of PxdsRNase genes were measured by RT-qPCR. EF1 was used as the reference gene for normalization. Statistical analyses were performed using one-way ANOVA followed by the Turkey test. (A) PxdsRNase1; (B) PxdsRNase2; (C) PxdsRNase3; (D) PxdsRNase4. ${ }^{*}, p<0.05 ; * *, p<0.01$ ).

A

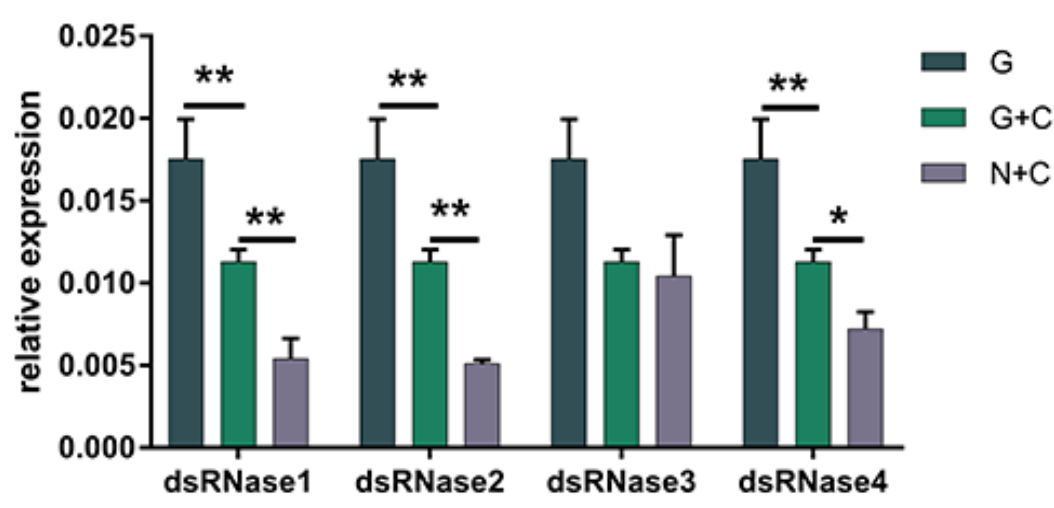

B

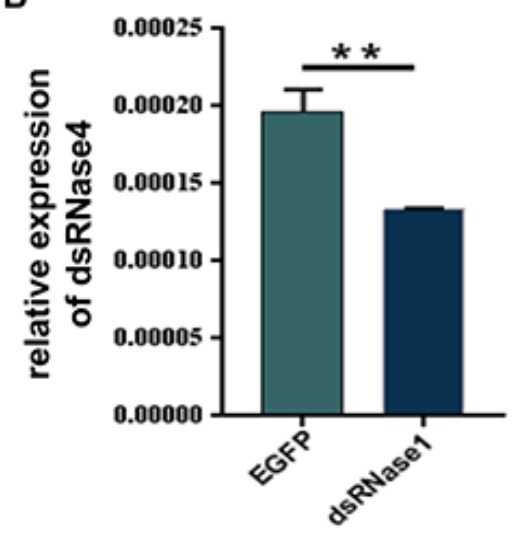

Figure 7. RNAi efficiency of $P x C h t$ after RNAi of $P x d s R N a s e$ by oral dsRNA. (A) Expression level of $P x C h t$ in the fourth instar larvae $60 \mathrm{~h}$ after oral administration of $1200 \mathrm{ng}$ of dsRNA of GFP, a mixture of dsGFP and dsPxCht $(\mathrm{G}+\mathrm{C})$ or a mixture of dsPxdsRNases and dsPxCht $(\mathrm{N}+\mathrm{C})$ was evaluated by RT-qPCR, and EF1 was used as the reference gene for normalization. Statistical analyses were performed using one-way ANOVA followed by the Turkey test. G, dsGFP; C, dsPxCht; N, dsPxdsRNase1/ dsPxdsRNase2/ dsPxdsRNase3/ dsPxdsRNase4. (B) PxdsRNase1 relative expression level in the fourth instar larvae $60 \mathrm{~h}$ after oral administration of dsPxdsRNase4. $\left({ }^{*}, p<0.05 ;{ }^{* *}, p<0.01\right)$.

\subsection{Enzymatic Activities of PxdsRNases}

The recombinant proteins, His-PxdsRNase1, His-PxdsRNase2, and His-PxdsRNase3, were successfully expressed in the prokaryotic expression system with the estimated molecular masses of $43 \mathrm{kDa}, 50 \mathrm{kDa}$, and $51 \mathrm{kDa}$, respectively (Figure 8), which were consistent with the expected protein sizes determined by the sequences. PxdsRNase1 showed a high dsRNase activity to degrade dsPxCht (Figure 9A), PxdsRNase2 had no effect 
on dsRNA (Figure 9B), and PxdsRNase3 cleaved dsRNA without complete degradation (Figure 9C).

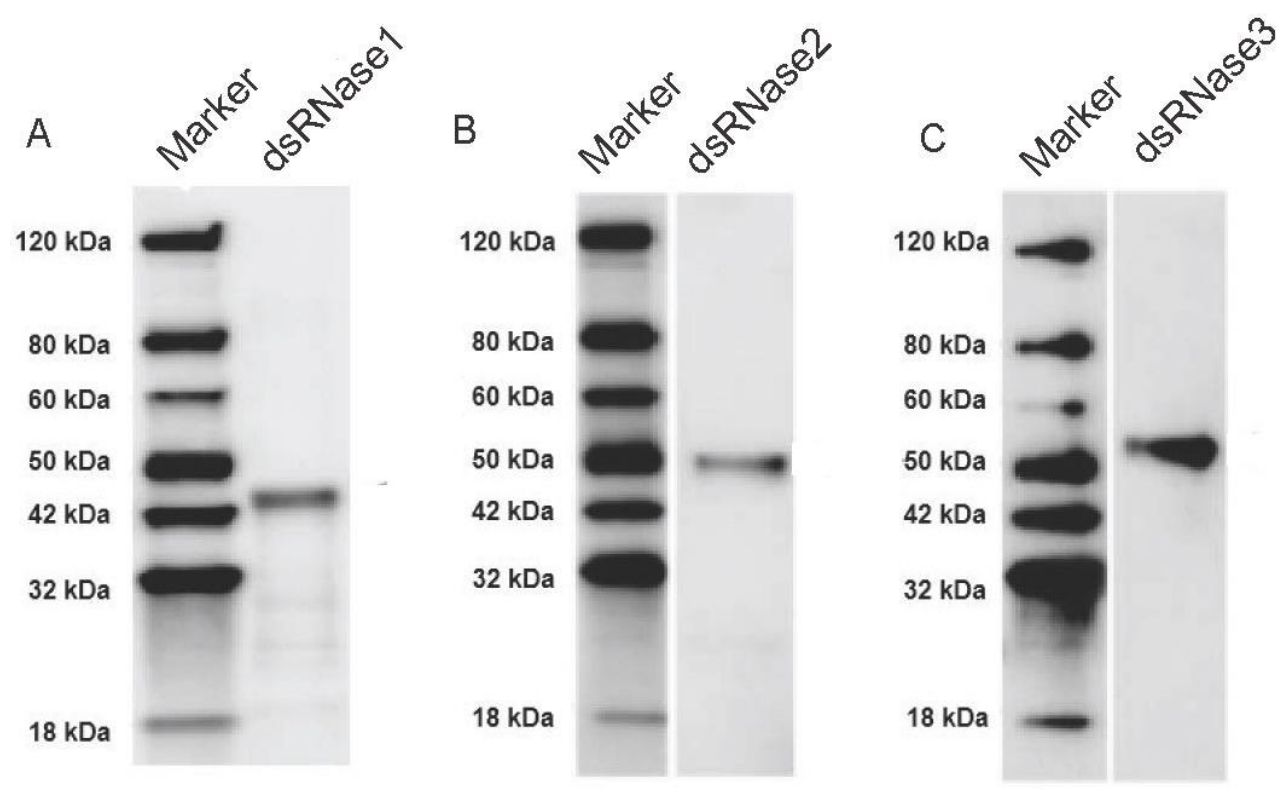

Figure 8. Western blot analysis of recombinant PxdsRNase proteins. Electrophoresis was performed in 12\% SDS-PAGE gel. The separated protein was transferred to membrane (100 V for $100 \mathrm{~min}$ ). After blocking with 5\% w/v BSA (Solarbio, Beijing, China), each protein was incubated with His monoclonal antibody (GenScript, Nanjing, China), separately. The EstinTM L1 staining kit (GenScript, Nanjing, China) was used for signal generation. The arrows point to the target proteins. (A) PxdsRNase1; (B) PxdsRNase2; (C) PxdsRNase3.

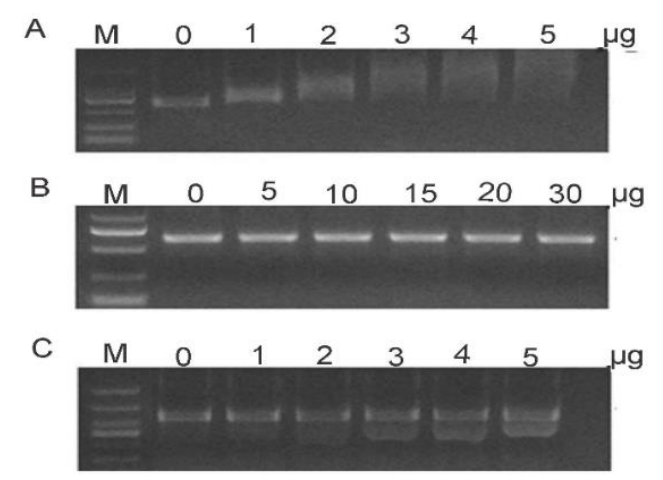

Figure 9. Degradation of dsRNA by recombinant PxdsRNases. M, marker. (A) PxdsRNase1; (B) PxdsRNase2; (C) PxdsRNase3.

\section{Discussion}

DsRNases are widely distributed in different organisms. The number of dsRNases varies from one to five among insects, such as, four dsRNases in L. migratoria and $S$. gregaria [13,15], three dsRNases in A. grandis [16], five dsRNases in S. litura and T. castaneum [18,23]. In P. xylostella, 4 dsRNases, PxdsRNase1, PxdsRNase2, PxdsRNase3 and PxdsRNase4, were identified. There is still no evidence to demonstrate that more dsRNases cause lower RNAi efficiency in one species. PxdsRNases shared similar conserved domains of endounuclease NS domain active site and substrate binding site with dsRNases in $B$. mori, L. migratoria, and S. gregaria $[8,13,15]$.

In P. xylostella, dsRNases were mainly expressed in the intestinal tract and hemolymph. DsRNases were mainly expressed in the head and intestine in T. castaneum [23], and in the intestines and salivary glands in Halyomorpha halys [24]. Therefore, dsRNase expression is 
inconsistent in different insects. The ability of total protein of hemolytic lymph to degrade dsRNA was higher than that of the intestinal juice in P. xylostella. Similar cases are reported in Lepidoptera and Coleoptera [25]. Expression of dsRNases, both in the intestinal tract and hemolymph, might be the reason why the injection of dsRNA is more effective than feeding dsRNA for RNAi in insects [2,25-27].

Not all dsRNases are always involved in the RNAi process in insects. PxdsRNase1/ PxdsRNase2/ PxdsRNase3 affected RNAi efficiency, and PxdsRNase4 without signal peptide had no effect on RNAi efficiency, neither through injection or oral intake of dsRNA. Similar case happens in S. litura, where four dsRNases could degrade dsRNA and the other one without signal peptide is not active [18]. Only LmdsRNase2 decreased the RNAi efficiency in L. migratoria [15], only dsRNase2 in S. gregaria $[13,28]$, and only dsRNase3 in Cylas puncticollis [29]. Therefore, the involvement of dsRNases in insects is species-specific. In addition to dsRNases, an RNAi efficiency-related nuclease (REase) is found to degrade dsRNA and suppress RNAi response in the Asian corn borer, Ostrinia furnacalis [19]. Uncovering the molecular mechanisms behind the phenomenon that some factors inhibit the initiation of RNAi responses is imperative to apply RNAi for the control of pests [30-32]. In our research, dsPxdsRNase4 did not suppress the expression PxdsRNase4, but PxdsRNase1 in oral experiment. This phenomenon is also found in the Asian migratory locust [13]. It is not clear whether similar situation will occur in other species and the mechanism behind this phenomenon is also uncovered.

PxdsRNase1 degraded dsRNA rapidly, PxdsRNase 3 cleaved dsRNA without complete degradation, and PxdsRNase2 could not degrade dsRNA. DsRNase activity depends on the $\mathrm{pH}$ of the working environment $[13,15]$. LmdsRNase1 could degrade dsRNA efficiently under the $\mathrm{pH}$ of 5 , and could be intensively suppressed at the physiological $\mathrm{pH}$ of hemolymph (7.0), leading to the long-term stability of dsRNA in the hemolymph [15]. In addition, the length of dsRNA could also affect dsRNase's activity [7]. Therefore, the effect of factors, including $\mathrm{pH}$ and the length of dsRNA on the activity of PxdsRNase, need to be investigated in the future to understand the stability of dsRNA in P. xylostella. In the meantime, new techniques, such as nanoparticles [33,34], transfection reagents [35], and dsRNA encapsulation using bacteria [36] are currently under the investigation by many groups for using RNAi technology as a new method for pest control. It is promising for RNAi-based pest control after the mechanism of dsRNase is explored.

\section{Conclusions}

We found four PxdsRNases, and three of them, PxdsRNase1, PxdsRNase2, and PxdsRNase 3 were verified to be involved in the RNAi process in P. xylostella. In vitro, the recombinant protein of PxdsRNase1 degraded dsRNA completely, and PxdsRNase 3 cleaved dsRNA without complete degradation. This study provided a fundamental basis for understanding the mechanism of dsRNase involvement in the RNAi process and using RNAi to control P. xylostella in the future.

Author Contributions: Conceptualization, G.Y., J.-Z.C. and Y.-X.J.; methodology, J.-Z.C. and Y.-X.J.; formal analysis, G.Y., J.-Z.C., Y.-X.J. and M.-W.L.; experimentation and data curation, J.-Z.C., Y.-X.J. and B.-H.Z.; writing-original draft preparation, J.-Z.C. and Y.-X.J.; writing-review and editing, G.Y., J.-Z.C., Y.-X.J. and J.-W.L.; visualization, J.-Z.C. and Y.-X.J.; supervision, G.Y.; funding acquisition, G.Y. All authors have read and agreed to the published version of the manuscript.

Funding: This project was supported by the National Natural Science Foundation of China (grant number: 31772237).

Institutional Review Board Statement: Not applicable.

Informed Consent Statement: Not applicable.

Data Availability Statement: Data are available from the article and from authors on request.

Conflicts of Interest: The authors declare no conflict of interest. 


\section{References}

1. Terenius, O.; Papanicolaou, A.; Garbutt, J.S.; Eleftherianos, I.; Huvenne, H.; Kanginakudru, S.; Albrechtsen, M.; An, C.; Aymeric, J.L.; Barthel, A.; et al. RNA interference in Lepidoptera: An overview of successful and unsuccessful studies and implications for experimental design. J. Insect Physiol. 2011, 57, 231-245. [CrossRef] [PubMed]

2. Luo, Y.; Wang, X.; Wang, X.; Yu, D.; Chen, B.; Kang, L. Differential responses of migratory locusts to systemic RNA interference via double-stranded RNA injection and feeding. Insect Mol. Biol. 2013, 22, 574-583. [CrossRef]

3. Shukla, J.N.; Kalsi, M.; Sethi, A.; Narva, K.E.; Fishilevich, E.; Singh, S.; Mogilicherla, K.; Palli, S.R. Reduced stability and intracellular transport of dsRNA contribute to poor RNAi response in lepidopteran insects. RNA Biol. 2016, 13, 656-669. [CrossRef] [PubMed]

4. Vatanparast, M.; Kim, Y. Optimization of recombinant bacteria expressing dsRNA to enhance insecticidal activity against a lepidopteran insect, Spodoptera exigua. PLoS ONE 2017, 12, e0183054. [CrossRef]

5. Cappelle, K.; de Oliveira, C.F.R.; Van Eynde, B.; Christiaens, O.; Smagghe, G. The involvement of clathrin-mediated endocytosis and two Sid-1-like transmembrane proteins in doublestranded RNA uptake in the Colorado potato beetle midgut. Insect Mol. Biol. 2016, 25, 315-323. [CrossRef]

6. Bolognesi, R.; Ramaseshadri, P.; Anderson, J.; Bachman, P.; Clinton, W.; Flannagan, R.; Ilagan, O.; Lawrence, C.; Levine, S.; Moar, W.; et al. Characterizing the mechanism of action of double-stranded RNA activity against western corn rootworm (Diabrotica virgifera virgifera LeConte). PLoS ONE 2012, 7, e47534. [CrossRef]

7. Wang, K.; Peng, Y.; Fu, W.; Shen, Z.; Han, Z. Key factors determining variations in RNA interference efficacy mediated by different double-stranded RNA lengths in Tribolium castaneum. Insect Mol. Biol. 2019, 28, 235-245. [CrossRef] [PubMed]

8. Arimatsu, Y.; Kotani, E.; Sugimura, Y.; Furusawa, T. Molecular characterization of a cDNA encoding extracellular dsRNase and its expression in the silkworm, Bombyx mori. Insect Biochem. Mol. Biol. 2007, 37, 176-183. [CrossRef]

9. Liu, J.H.; Swevers, L.; Iatrou, K.; Huvenne, H.; Smagghe, G. Bombyx mori DNA/RNA non-specific nuclease: Expression of isoforms in insect culture cells, subcellular localization and functional assays. J. Insect Physiol. 2012, 58, 1166-1176. [CrossRef] [PubMed]

10. Allen, M.L.; Walker, W.B. Saliva of Lygus lineolaris digests double stranded ribonucleic acids. J. Insect Physiol. 2012, 58, 391-396. [CrossRef]

11. Garbutt, J.S.; Belles, X.; Richards, E.H.; Reynolds, S.E. Persistence of double-stranded RNA in insect hemolymph as a potential determiner of RNA interference success: Evidence from Manduca sexta and Blattella germanica. J. Insect Physiol. 2013, 59, 171-178. [CrossRef] [PubMed]

12. Christiaens, O.; Swevers, L.; Smagghe, G. DsRNA degradation in the pea aphid (Acyrthosiphon pisum) associated with lack of response in RNAi feeding and injection assay. Peptides 2014, 53, 307-314. [CrossRef] [PubMed]

13. Wynant, N.; Santos, D.; Verdonck, R.; Spit, J.; Van Wielendaele, P.; Vanden Broeck, J. Identification, functional characterization and phylogenetic analysis of double stranded RNA degrading enzymes present in the gut of the desert locust, Schistocerca gregaria. Insect Biochem. Mol. Biol. 2014, 46, 1-8. [CrossRef] [PubMed]

14. Yoon, J.S.; Gurusamy, D.; Palli, S.R. Accumulation of dsRNA in endosomes contributes to inefficient RNA interference in the fall armyworm, Spodoptera frugiperda. Insect Biochem. Mol. Biol. 2017, 90, 53-60. [CrossRef]

15. Song, H.; Zhang, J.; Li, D.; Cooper, A.M.W.; Silver, K.; Li, T.; Liu, X.; Ma, E.; Zhu, K.Y.; Zhang, J. A double-stranded RNA degrading enzyme reduces the efficiency of oral RNA interference in migratory locust. Insect Biochem. Mol. Biol. 2017, 86, 68-80. [CrossRef]

16. Garcia, R.A.; Macedo, L.L.P.; Do Nascimento, D.C.; Gillet, F.X.; Moreira-Pinto, C.E.; Faheem, M.; Basso, A.M.M.; Silva, M.C.M.; Grossi-de-Sa, M.F. Nucleases as a barrier to gene silencing in the cotton boll weevil, Anthonomus grandis. PLoS ONE 2017, 12, e0189600.

17. Peng, Y.C.; Wang, K.X.; Fu, W.X.; Sheng, C.W.; Han, Z.J. Biochemical comparison of dsRNA degrading nucleases in four different insects. Front. Physiol. 2018, 9, 624. [CrossRef]

18. Peng, Y.C.; Wang, K.X.; Zhu, G.H.; Han, Q.X.; Chen, J.S.; Elzaki, M.E.A.; Sheng, C.W.; Zhao, C.Q.; Palli, S.R.; Han, Z.J. Identification and characterization of multiple dsRNases from a lepidopteran insect, the tobacco cutworm, Spodoptera litura (Lepidoptera: Noctuidae). Pest. Biochem. Physiol. 2020, 162, 86-95. [CrossRef]

19. Guan, R.B.; Li, H.C.; Fan, Y.J.; Hu, S.R.; Christiaens, O.; Smagghe, G.; Miao, X.X. A nuclease specific to lepidopteran insects suppresses RNAi. J. Biol. Chem. 2018, 293, 6011-6021. [CrossRef] [PubMed]

20. Huang, Y.P.; Wang, Y.J.; Zeng, B.S.; Liu, Z.X.; Xu, X.J.; Meng, Q.; Huang, Y.P.; Yang, G.; Vasseur, L.; Gurr, G.M.; et al. Functional characterization of Pol III U6 promoters for gene knockdown and knockout in Plutella xylostella. Insect Biochem. Mol. Biol. 2017, 89, 71-78. [CrossRef]

21. He, Z.X.; Chen, J.; Ran, X.Y.; Chen, X.; Bai, Y.; Xie, X.M.; Hou, T.W. Prokaryotic expression and immunogenicity analysis of phosphoglycerate kinase 1 of Candida albicans. Chin. J. Cell. Mol. Immunol. 2013, 29, 1079-1081. [CrossRef]

22. Grabski, A.C. Advances in preparation of biological extracts for protein purification. In Guide to Protein Purification, 2nd ed.; Burgess, R.R., Deutscher, M.P., Eds.; Elsevier Academic Press Inc.: San Diego, CA, USA, 2009; Volume 463, pp. $285-303$.

23. Peng, Y.C.; Wang, K.X.; Chen, J.S.; Wang, J.D.; Zhang, H.N.; Ze, L.J.; Zhu, G.H.; Zhao, C.Q.; Xiao, H.J.; Han, Z.J. Identification of a double-stranded RNA-degrading nuclease influencing both ingestion and injection RNA interference efficiency in the red flour beetle Tribolium castaneum. Insect Biochem. Mol. Biol. 2020, 125, 103440. [CrossRef] [PubMed] 
24. Lomate, P.R.; Bonning, B.C. Proteases and nucleases involved in the biphasic digestion process of the brown marmorated stink bug, Halyomorpha halys (Hemiptera: Pentatomidae). Arch. Insect Biochem. Physiol. 2018, 98, e21459. [CrossRef] [PubMed]

25. Wang, K.; Peng, Y.; Pu, J.; Fu, W.; Wang, J.; Han, Z. Variation in RNAi efficacy among insect species is attributable to dsRNA degradation in vivo. Insect Biochem. Mol. Biol. 2016, 77, 1-9. [CrossRef] [PubMed]

26. Joga, M.R.; Zotti, M.J.; Smagghe, G.; Christiaens, O. RNAi efficiency, systemic properties, and novel delivery methods for pest insect control: What we know so far. Front. Physiol. 2016, 7, 553. [CrossRef]

27. Sapountzis, P.; Duport, G.; Balmand, S.; Gaget, K.; Jaubert-Possamai, S.; Febvay, G.; Charles, H.; Rahbe, Y.; Colella, S.; Calevro, F. New insight into the RNA interference response against cathepsin-L gene in the pea aphid, Acyrthosiphon pisum: Molting or gut phenotypes specifically induced by injection or feeding treatments. Insect Biochem. Mol. Biol. 2014, 51, 20-32. [CrossRef]

28. Spit, J.; Philips, A.; Wynant, N.; Santos, D.; Plaetinck, G.; Broeck, J.V. Knockdown of nuclease activity in the gut enhances RNAi efficiency in the Colorado potato beetle, Leptinotarsa decemlineata, but not in the desert locust, Schistocerca gregaria. Insect Biochem. Mol. Biol. 2017, 81, 103-116. [CrossRef]

29. Prentice, K.; Smagghe, G.; Gheysen, G.; Christians, O. Nuclease activity decreases the RNAi response in the sweetpotato weevil Cylas puncticollis. Insect Biochem. Mol. Biol. 2019, 110, 80-89. [CrossRef]

30. Yu, N.; Christiaens, O.; Liu, J.; Niu, J.; Cappelle, K.; Caccia, S.; Huvenne, H.; Smagghe, G. Delivery of dsRNA for RNAi in insects: An overview and future directions. Insect Sci. 2013, 20, 4-14. [CrossRef]

31. Machado, V.; Rodriguez-Garcia, M.J.; Sanchez-Garcia, F.J.; Galian, J. RNA Interference: A new strategy in the evolutionary arms race between human control strategies and insect pests. Folia Biol. Krakow 2014, 62, 335-343. [CrossRef]

32. Rodrigues, T.B.; Figueira, A. Management of insect pest by RNAi-A new tool for crop protection. In RNA Interference; Abdurakhmonov, I.Y., Ed.; InTech: London, UK, 2016; pp. 371-390. [CrossRef]

33. Zhang, X.; Zhang, J.; Zhu, K.Y. Chitosan/double-stranded RNA nanoparticle-mediated RNA interference to silence chitin synthase genes through larval feeding in the African malaria mosquito (Anopheles gambiae). Insect Mol. Biol. 2010, 19, 683-693. [CrossRef] [PubMed]

34. He, B.C.; Chu, Y.; Yin, M.Z.; Mullen, K.; An, C.J.; Shen, J. Fluorescent nanoparticle delivered dsRNA toward genetic control of insect pests. Adv. Mater. 2013, 25, 4580-4584. [CrossRef] [PubMed]

35. Sanitt, P.; Apiratikul, N.; Niyomtham, N.; Yingyongnarongkul, B.E.; Assavalapsakul, W.; Panyim, S.; Udomkit, A. Cholesterolbased cationic liposome increases dsRNA protection of yellow head virus infection in Penaeus vannamei. J. Biotechnol. 2016, 228, 95-102. [CrossRef] [PubMed]

36. Yang, J.; Han, Z.J. Efficiency of different methods for dsRNA delivery in cotton bollworm (Helicoverpa armigera). J. Integr. Agric. 2014, 13, 115-123. [CrossRef] 